\title{
Genetic and Phenotypic Parameter Estimates of Total and Partial Lifetime Traits for Dairy Ewes
}

\author{
U. M. El-Saied, ${ }^{1, \star}$ L. F. De La Fuente, ${ }^{2}$ J. A. Carriedo, ${ }^{2}$ and F. San Primitivo ${ }^{2}$ \\ ${ }^{1}$ Animal Production Research Institute, Dokki, Giza, Egypt \\ ${ }^{2}$ Departamento de Producción Animal I, Facultad de Veterinaria, \\ Universidad de León, 24071 León, Spain
}

\section{ABSTRACT}

A data file with 11,547 lactations for 2602 Spanish Churra ewes, daughters of 100 sires and 2179 dams, was used to estimate genetic and phenotypic parameters of total and partial lifetime traits with a multipletrait animal model using REML. These ewes first lambed between 1992 and 1998 and belonged to 27 flocks enrolled in the nucleus scheme of the breed. The study took into account 4 life span traits, 2 productive traits, and 2 reproductive traits. Lifetime revenues from milk and lambs were calculated. Daily traits for both milk and revenues of lifetime, productive life, and useful life were also calculated. Partial lifetime traits were considered for the first 3 parities. The model included flock and birth year within flock as fixed effects and animal as a random effect. Both fixed effects contributed significantly to variation of all total lifetime traits. Milk production level was included in the model as a covariable to adjust life span traits. Heritability estimates for life span traits were low (0.02 to 0.06), indicating few possibilities for direct genetic selection. Genetic and phenotypic correlations among life span traits averaged 0.90 and 0.87 , respectively. Heritabilities for daily milk and revenue traits were always higher than those for their corresponding lifetime traits. Heritability for milk yield per day of useful life was 0.25 $( \pm 0.04)$. Heritability estimates for partial lifetime performance traits increased notably when more parities were included (from the first parity to the first 3 parities). Their genetic and phenotypic correlations with total lifetime traits also increased gradually when more information was considered. These results indicate that possibilities for early genetic selection for some lifetime traits are not totally excluded.

(Key words: genetic parameter, lifetime trait, dairy ewe)

Received March 29, 2005.

Accepted May 19, 2005.

Corresponding author: U. M. El-Saied, e-mail: umelsaied2003@ yahoo.com.

*Present mailing address: Departamento de Producción Animal I, Facultad de Veterinaria, Universidad de León, 24071 León, Spain.

\section{INTRODUCTION}

As is the case for numerous dairy breeds in several countries, genetic selection in Churra dairy ewes has placed the primary emphasis on milk production for many years. In the last $5 \mathrm{yr}$, however, increasing interest has been paid to selection for additional traits including protein percentage and udder and type traits to increase profitability.

Longevity, or length of lifetime, can be seen as a composite of production, health, and reproduction (Mulder and Jansen, 1999). A profitable female can maintain elevated milk yields for many years with acceptable reproduction and body conformation and without serious health problems. The lifetime is determined by culling decisions of individual producers. Dekkers (1993) indicated that most culling decisions are economic in nature, and a female is replaced because higher profit is expected from her replacement. Culling decisions are either voluntary, as a function of the level of production of the individual, or involuntary, depending on a set of causes including health disorders (mastitis, lameness, etc.), low reproductive performance, and death (Vollema and Groen, 1995; Boettcher et al., 1999).

Long lifetime means good health and fertility, allows the animal to achieve its maximum productive capacity, contributes to reducing replacement and treatment costs, and increases the scope of voluntary culling (Dekkers, 1993; Jairath et al., 1994; Boettcher et al., 1997). Because of its effect on economic performance, lifetime has been seen as a trait of interest for animal breeders, in general, and dairy breeders, in particular (Allaire and Gibson, 1992; Dekkers et al., 1994; Pérez-Cabal and Alenda, 2003). Rogers et al. (1988) and Van Arendonk (1991) stated that milk yield and longevity are the 2 most important traits for overall lifetime merit.

Boettcher et al. (1997, 1999) and Visscher et al. (2001) pointed out that direct genetic improvement for herd life is difficult for many reasons, including that it is measured in females only and late in life, as complete records are unavailable until the animal is culled. Moreover, lifetime traits tend to be lowly heritable. Alterna- 
Table 1. Description of the set of data for total lifetime performance traits.

\begin{tabular}{lc}
\hline Characteristic & Value \\
\hline Ewes with records, no. & 2602 \\
Lactations, no. & 11,547 \\
Sires, no. & 100 \\
Daughters per sire, range & $5-186$ \\
Flocks, no. & 27 \\
Connected flocks by each sire, range & $2-25$ \\
Dams, no. & 2179 \\
Dams with records, no. & 230 \\
Parities per ewe, range & $1-14$ \\
Years of birth of ewes & 1990 to 1995 , inclusive \\
Years of lambing & 1992 to 2003, inclusive \\
\hline
\end{tabular}

tives to direct selection for lifetime include the use of different measures of herd life that can be recorded relatively early in life (Jairath et al., 1994) or performing indirect selection through information on nonsurvival traits that are genetically associated with herd life (Jairath and Dekkers, 1996). Weigel et al. (1995) stated that indirect selection for lifetime merit is usually the method of choice because evaluation can be based on traits measured earlier in life.

There is a lack of research work on lifetime performance for dairy ewes. The objective of this work was to estimate genetic and phenotypic parameters of several total and partial lifetime performance traits and investigate improvement possibilities in Churra dairy ewes.

\section{MATERIALS AND METHODS}

\section{Data}

Data were obtained from the National Association of Spanish Churra Breeders (ANCHE, Palencia, Spain) and were collected between 1990 and 2003. Table 1 presents a summary of the data set analyzed in this work. A total of 11,547 lactation records including dates of birth, lambing, dry off, and culling; and yields for milk and lambs were used to calculate 2602 lifetime records of the Spanish Churra dairy ewes belonging to 27 flocks integrated in the nucleus scheme of the breed. Late gestation ewes are usually kept together in a single yard; many of them give birth to multiple lambs. To prevent wrong dam-lamb assignation, pedigree control is regularly done by the Department of Animal Production I, University of León (León, Spain), using DNA genetic markers on sample individuals from all those flocks integrated into the nucleus scheme of the Churra breed.

All ewes were daughters of AI sires and were artificially inseminated themselves; therefore, complete pedigree information was available over the study period. A restriction that each sire have at least 5 daughters was imposed to ensure genetic connections among the flocks included. Fifty-two percent of the sires had $\geq 10$ daughters and $42 \%$ had daughters in $\geq 5$ flocks. Therefore, many genetic links existed among the flocks because of extensive use of AI. Ewes were permanently housed indoors at night and grazed during the day under stable management and nutritional conditions. The suckling period averaged $30 \mathrm{~d}$, and ewes were milked for approximately $120 \mathrm{~d}$ after weaning. Lambs were typically slaughtered after weaning to meet the market demand. Details on yield recording and management of these flocks are available in the work of El-Saied et al. (1998, 1999) and Gonzalo et al. (2005).

All ewes had to have consecutive lactations, starting with the first. Birth dates were between 1990 and 1995; therefore, the youngest ewes had at least $9 \mathrm{yr}$ of opportunity of life. Lambing dates were between 1992 and 2003, inclusive. An age at first lambing between 12 and 36 mo was required, and lambing interval was restricted to between 180 and $599 \mathrm{~d}$. The end of data recording was marked by mortality, accidents, health disorders, or low production. Unfortunately, reasons for culling were not recorded for each individual ewe. For modeling purposes, all ewes had to remain in the same flock throughout their lives.

\section{Variables}

The present study included 2 productive traits: total lifetime milk yield and the number of lambs sold at weaning during the lifetime of each ewe. Lifetime productivities from both milk and lambs were transformed into their equivalent sums of revenues according to their prices. The milk and lamb pricing systems did not change during the time of data recording, and average prices were 6.3 Eurocent/L of milk and 48 Euro per lamb at weaning. Churra milk is exclusively made into cheese. Therefore, milk composition of protein and fat is the determining factor of yield and quality of the final product and, consequently, of milk price. Detailed information on this aspect is available in the work of Othmane et al. (2002). In the present study, revenues from milk were calculated as a function of the quantity of sold milk yield and its content in protein and fat. Reproductive performance traits included age at lambing and average interval between consecutive lactations during the lifetime of each ewe.

The literature presents various measures for life span. Because of the lack of research work on lifetime performance for dairy ewes, it was decided to evaluate several lifetime performance traits for 2 reasons: 1 ) to describe ewe lifetime completely, and 2) to estimate genetic correlations among total and partial lifetime performance traits and investigate early improvement 
Table 2. Phenotypic means, standard deviations (SD), minima (Min.), maxima (Max.), and coefficients of variation $(\mathrm{CV})$ for total lifetime performance traits. ${ }^{1}$

\begin{tabular}{|c|c|c|c|c|c|}
\hline \multirow[b]{2}{*}{ Trait $^{2}$} & \multirow[b]{2}{*}{ Mean } & \multirow[b]{2}{*}{ SD } & \multicolumn{2}{|c|}{ Range } & \multirow[b]{2}{*}{$\mathrm{CV}(\%)$} \\
\hline & & & Min. & Max. & \\
\hline LT, d & 2165 & 751 & 537 & 4370 & 33 \\
\hline PL, d & 1216 & 738 & 65 & 3709 & 57 \\
\hline $\mathrm{UL}, \mathrm{d}$ & 618 & 359 & 65 & 1990 & 53 \\
\hline TMY, l & 610 & 442 & 32 & 2673 & 66 \\
\hline $\mathrm{M} / \mathrm{dLT}, \mathrm{l}$ & 0.26 & 0.13 & 0.03 & 0.84 & 43 \\
\hline $\mathrm{M} / \mathrm{dPL}, \mathrm{l}$ & 0.52 & 0.21 & 0.10 & 1.98 & 38 \\
\hline M/dUL, l & 0.94 & 0.29 & 0.21 & 2.77 & 28 \\
\hline Age1L, d & 604 & 159 & 365 & 1098 & 25 \\
\hline Lifetime score & 4.4 & 2.5 & 1 & 14 & 51 \\
\hline Interv & 325 & 59 & 195 & 594 & 16 \\
\hline Lambs & 6.2 & 3.8 & 1 & 21 & 56 \\
\hline TRLT, Euro & 700 & 464 & 67 & 2723 & 60 \\
\hline R/dLT, Euro & 0.30 & 0.13 & 0.05 & 0.76 & 36 \\
\hline R/dPL, Euro & 0.60 & 0.20 & 0.23 & 2.17 & 31 \\
\hline R/dUL, Euro & 1.10 & 0.23 & 0.43 & 2.29 & 19 \\
\hline
\end{tabular}

${ }^{1}$ Number of analyzed records $=2602$ for all variables except for average interval between successive lambings, which had 2453 records.

${ }^{2} \mathrm{LT}=$ Lifetime, $\mathrm{PL}=$ productive life, $\mathrm{UL}=$ useful life, $\mathrm{TMY}=$ total milk yield, $\mathrm{M} / \mathrm{dLT}=$ milk per day of lifetime, $\mathrm{M} / \mathrm{dPL}=$ milk per day of productive life, $\mathrm{M} / \mathrm{dUL}=$ milk per day of useful life, Age1L = age at first lambing, lifetime score $=$ number of given parities during lifetime, Interv $=$ average interval between successive lambings, lambs = lambs sold at weaning during LT, TRLT $=$ total revenues from milk and lambs during lifetime, R/dLT = revenue from milk and lambs per day of lifetime, R/dPL = revenue from milk and lambs per day of productive life, and R/dUL = revenue from milk and lambs per day of useful life.

possibilities during lifetime. Thus, complete observations were required, and this is only possible for ewes with recorded culling dates (i.e., no censored records were present). The present study considered 4 variables related to the life of the ewe including 1) total lifetime (number of days between birth and culling), 2) productive life (length of time between first lambing and the last dry date), 3) useful life (total number of DIM during lifetime), and 4) lifetime score (i.e., the number of lactations a ewe survived). Dekkers (1993) mentioned that length of productive life is a trait of major economic importance as it combines productive and reproductive aspects, excluding age at first parity.

Two intervals of time that are unprofitable from a milk production standpoint are the period from birth to first parturition and dry periods (Lormore and Galligan, 2001). These periods represent nonproductive days that dilute the profit of production per day of life. Therefore, other measures for life span were added that considered both productivity and life span. These measures included 1) milk per day for lifetime, productive life, and useful life and 2) total revenues from milk and lambs per day for lifetime, productive life, and useful life.

Partial lifetime traits were also calculated for the first 3 lambings. Traits included age at each lambing; lifetime; productive life; useful life; milk yield per day of lifetime, productive life, and useful life; and cumulative lifetime revenues from sold milk and weaned lambs at the end of each parity.

\section{Statistical Analyses}

Genetic parameters were estimated using REML and the VCE 4.0 software (Groeneveld and García Cortés, 1998) with the following multiple-trait animal model:

$$
\mathbf{Y}_{\mathrm{ijkl}}=\mathbf{F}_{\mathrm{i}}+\mathbf{Y B}_{\mathrm{ij}}+\mathbf{A}_{\mathrm{k}}+\varepsilon_{\mathrm{ijkl}}
$$

where:

$\mathrm{Y}_{\mathrm{ijkl}}=$ productive and reproductive total or partial lifetime traits;

$F_{i}=$ fixed effect of flock i (27 levels);

$\mathrm{YB}_{\mathrm{ij}}=$ fixed effect of year of birth $\mathrm{j}$ within flock $\mathrm{i}(116$ levels);

$\mathrm{A}_{\mathrm{k}}=$ random additive genetic effect of individual $\mathrm{k}$; and

$\varepsilon_{\mathrm{ijkl}}=$ random residual effect.

The model just described was a linear model. In theory, survival analysis is a more appropriate statistical method for analysis of lifetime traits because it deals properly with the typically skewed distributions of the data and can account for censored records. However, the use of the linear model was justifiable in this work. First, only uncensored records were used. Second, previous results for dairy cows (Jairath et al., 1994) indicated that REML estimates from a linear model can be of practical use even when normality does not hold. Life 
Table 3. Phenotypic means, standard deviations (SD), minimums (Min.), maximums (Max.), and coefficients of variation $(\mathrm{CV})$ for partial lifetime performance traits.

\begin{tabular}{|c|c|c|c|c|c|}
\hline \multirow[b]{2}{*}{ Trait $^{1}$} & \multirow[b]{2}{*}{ Mean } & \multirow[b]{2}{*}{ SD } & \multicolumn{2}{|c|}{ Range } & \multirow[b]{2}{*}{$\mathrm{CV}(\%)$} \\
\hline & & & Min. & Ma. & \\
\hline Age1L, d & 604 & 159 & 365 & 1098 & 25 \\
\hline Age2L, d & 930 & 173 & 595 & 1617 & 17 \\
\hline Age3L, d & 1251 & 190 & 840 & 1921 & 14 \\
\hline PL2, d & 467 & 81 & 262 & 757 & 16 \\
\hline PL3, d & 791 & 120 & 508 & 1261 & 13 \\
\hline UL1, d & 142 & 23 & 60 & 207 & 16 \\
\hline UL2, d & 281 & 38 & 133 & 387 & 13 \\
\hline UL3, d & 426 & 48 & 194 & 566 & 10 \\
\hline MY1, l & 123 & 50 & 32 & 340 & 38 \\
\hline MY2, 1 & 259 & 95 & 63 & 799 & 34 \\
\hline MY3, l & 413 & 139 & 95 & 1191 & 30 \\
\hline $\mathrm{M} / \mathrm{dLT} 1, \mathrm{l}$ & 0.17 & 0.07 & 0.03 & 0.64 & 39 \\
\hline $\mathrm{M} / \mathrm{dLT} 2, \mathrm{l}$ & 0.22 & 0.08 & 0.04 & 0.77 & 32 \\
\hline $\mathrm{M} / \mathrm{dLT} 3, \mathrm{l}$ & 0.25 & 0.08 & 0.01 & 0.78 & 29 \\
\hline $\mathrm{M} / \mathrm{dPL} 2, \mathrm{l}$ & 0.56 & 0.20 & 0.10 & 1.58 & 33 \\
\hline M/dPL3, l & 0.53 & 0.18 & 0.13 & 1.39 & 29 \\
\hline M/dUL1, l & 0.87 & 0.33 & 0.19 & 2.68 & 35 \\
\hline M/dUL2, 1 & 0.91 & 0.30 & 0.21 & 2.91 & 30 \\
\hline $\mathrm{M} / \mathrm{dUL3}, \mathrm{l}$ & 0.96 & 0.29 & 0.31 & 2.84 & 27 \\
\hline R1, Euro & 138 & 42 & 19 & 463 & 29 \\
\hline R2, Euro & 294 & 77 & 127 & 664 & 24 \\
\hline R3, Euro & 471 & 112 & 204 & 1015 & 21 \\
\hline
\end{tabular}

${ }^{1}$ Age1L = Age at first lambing, Age2L = age at second lambing, Age3L = age at third lambing, PL2 = 2parity productive life, PL3 = 3-parity productive life, UL1 = first parity useful life, UL2 = 2-parity useful life, UL3 = 3-parity useful life, MY1 = milk yield of first parity, MY2 = commulative milk yield of first 2 parities, MY3 = commulative milk yield of first 3 parities, M/dLT1 = milk per day of lifetime at end of first parity, M/dLT2 = milk per day of lifetime at end of second parity, M/dLT3 = milk per day of lifetime at end of third parity, M/dPL2 = milk per day of productive life at end of second parity, M/dPL3 = milk per day of productive life at end of third parity, M/dUL1 = milk per day of useful life at end of first parity, M/ dUL2 = milk per day of useful life at end of second parity, M/dUL3 = milk per day of useful life at end of third parity, R1 = revenue from milk and lambs at end of first parity, $\mathrm{R} 2$ = revenue from milk and lambs at end of second parity, and R3 = revenue from milk and lambs at end of third parity.

span traits (lifetime, productive life, useful life, and lifetime score) were adjusted for milk production level, introducing milk per day of useful life as a covariable in the previously mentioned model. The model was used separately to analyze partial lifetime traits (first parity, cumulative first and second parities, and cumulative first, second, and third parities). In all cases, a single observation per ewe was analyzed. All known relationships among individuals were considered in the animal model. Descriptive statistics were estimated by SAS (1998).

\section{RESULTS AND DISCUSSION}

Tables 2 and 3 present phenotypic means, standard deviations, minimums, maximums, and coefficients of variation for total and partial lifetime performance traits, respectively. Total lifetime and productive life averaged 2165 and $1216 \mathrm{~d}$, respectively. Conington et al. (2001) reported that longevity of Hill ewes in UK averaged $1756 \mathrm{~d}$. This estimate cannot be compared directly with that for Churra ewes, however, because of differences in both the pattern of production and breeding objectives. Hill sheep are a grazing breed that are mainly used for meat production. The main goals of their breeding program are improving maternal performance and carcass and growth characteristics of lambs. Available literature does not provide information on dairy ewes.

As can be seen in Table 2, the phenotypic coefficient of variation ranged from 53 to $66 \%$ and averaged $57 \%$ for productive life, useful life, total milk yield during the lifetime, lifetime score, lambs sold at weaning during lifetime of the ewe, and total revenues from milk and lambs during lifetime. Both milk and revenues per day of lifetime, productive life, and useful life had lower values for the coefficient of variation, averaging $32 \%$. The standardization effect on per-day traits by days of life may explain this difference. In the current study, lifetime score (number of given parities per ewe during lifetime) ranged between 1 and 14 parities. Figure 1 shows the survival curve for Churra ewes.

Nonproductive periods, the time from birth to first parturition and cumulative dry periods during lifetime, averaged 618 and $598 \mathrm{~d}$, respectively. The means for both traits are greater than desired from an economic 


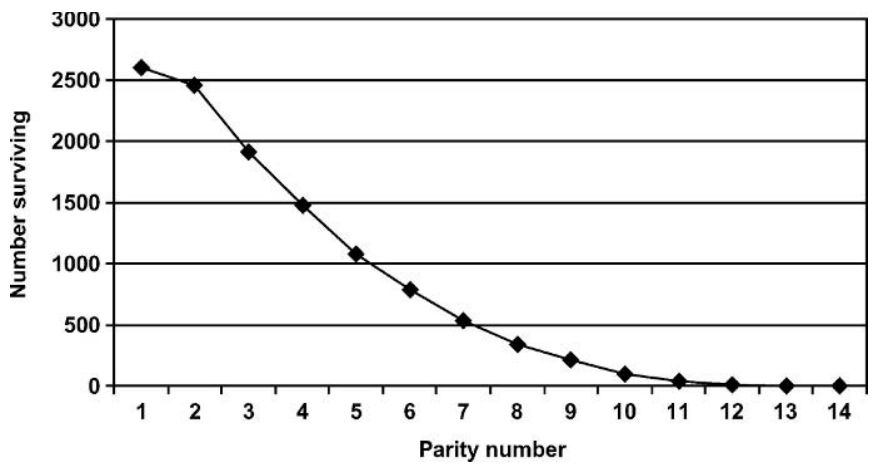

Figure 1. Survival curve for Churra ewes along with parity number.

point-of-view and are directly affected by the reproductive efficiency of the ewe. Therefore, more attention should be paid to improving reproductive performance of the Churra breed. Improving reproductive performance would help to increase profitability of dairy sheep farms.

The average useful life observed was $618 \mathrm{~d}$, which corresponds to an average of $140 \mathrm{~d}$ per parity. This result is consistent with accepted management practices inasmuch as the average suckling period in Churra is $30 \mathrm{~d}$, after which ewes are usually milked for approximately $120 \mathrm{~d}$. Partial useful life averaged 142,139 , and $145 \mathrm{~d}$ for first, second, and third parities, respectively.

The average lifetime milk yield in this study was 610 $\mathrm{L}$ (i.e., an average of $138 \mathrm{~L}$ per lactation). Average milk yield of the first 3 lactations was 123, 136, and $154 \mathrm{~L}$, respectively. Previous studies on Churra breed (Carriedo et al., 1995; El-Saied et al., 1998, 1999) reported standardized 120-d milk yield ranging between 102 and 133 L. Previous studies on Churra dairy ewes (Baro et al., 1994; El-Saied et al., 1998; Fuertes et al., 1998) found that daily milk yield ranged between 0.85 and $1.10 \mathrm{~L}$. Our estimate of milk per day of useful life from this study (0.94) falls within this range.

Milk per day over lifetime averaged 0.26 L (Table 2). Results in Table 3 show that milk per day of useful life gradually increased with parity number. Estimates increased from 0.17 to 0.25 (Table 3 ) when more parities were included in calculating partial lifetime traits. Although both partial milk yield and lactation length were higher for records of $3 \mathrm{vs} .2$ parities and although milk per day of useful life increased gradually with more parities included, milk per day of productive life decreased from 0.56 after 2 parities to 0.53 after 3 parities. The main reason behind this decrease was the relatively long dry period between second and third parity $(179 \mathrm{~d})$. The lower the nonproductive periods, the lower
Table 4. Analysis of variance of total lifetime performance traits. ${ }^{1}$

\begin{tabular}{|c|c|c|c|}
\hline \multirow[b]{2}{*}{ Trait } & \multicolumn{3}{|c|}{$F$-value and significance } \\
\hline & Flock & $\begin{array}{l}\text { Year of } \\
\text { birth } \\
\text { (flock) }\end{array}$ & $\begin{array}{l}\text { Milk } \\
\text { production } \\
\text { level }\end{array}$ \\
\hline LT, d & $6.80^{* * *}$ & $2.02 * * *$ & $166.41^{* * *}$ \\
\hline $\mathrm{PL}, \mathrm{d}$ & $6.53^{* * * *}$ & $1.46 * * *$ & $161.39 * * *$ \\
\hline UL, d & $10.58 * * *$ & $1.37 * * *$ & $182.06 * * *$ \\
\hline TMY, 1 & $13.85^{* * *}$ & $1.36 * *$ & - \\
\hline $\mathrm{M} / \mathrm{dLT}, \mathrm{l}$ & $19.22^{* * *}$ & $1.60 * *$ & - \\
\hline $\mathrm{M} / \mathrm{dPL}, \mathrm{l}$ & $10.56^{* * *}$ & $1.80 * * *$ & - \\
\hline $\mathrm{M} / \mathrm{dUL}, \mathrm{l}$ & $13.97 * * *$ & $1.74 * * *$ & - \\
\hline Age1L, d & $9.98 * * *$ & $5.21^{* * *}$ & - \\
\hline Lifetime score & $10.55^{* * *}$ & $1.39 * *$ & $131.96 * * *$ \\
\hline Interv & $15.75^{* *}$ & $2.56^{* * * *}$ & - \\
\hline Lambs & $12.58 * * *$ & $1.45^{* * *}$ & - \\
\hline TRLT & $14.27 * * *$ & $1.36 * *$ & - \\
\hline $\mathrm{R} / \mathrm{dLT}$ & $21.14 * * *$ & $1.61 * * *$ & - \\
\hline $\mathrm{R} / \mathrm{dPL}$ & $8.87 * * *$ & $2.12 * * *$ & - \\
\hline R/dUL & $11.67 * * *$ & $1.63^{* * * *}$ & - \\
\hline
\end{tabular}

${ }^{1} \mathrm{LT}=$ Lifetime, $\mathrm{PL}=$ productive life, $\mathrm{UL}=$ useful life, $\mathrm{TMY}=$ total milk yield, M/dLT = milk per day of lifetime, $\mathrm{M} / \mathrm{dPL}=$ milk per day of productive life, M/dUL = milk per day of useful life, Age1L = age at first lambing, lifetime score = number of given parities during LT, Interv = average interval between successive lambings, lambs = lambs sold at weaning during LT, TRLT = total revenue from milk and lambs during lifetime, R/dLT = revenue from milk and lambs per day of lifetime, $\mathrm{R} / \mathrm{dPL}=$ revenue from milk and lambs per day of productive life, and R/UL = revenue from milk and lambs per day of useful life.

$* * * P<0.001 ; * * P<0.01$.

the fixed maintenance cost of the animal. However, suitable dry periods are necessary as a biological and financial investment in the future profitability of the animal (Lormore and Galligan, 2001).

The average number of lambs sold at weaning during a lifetime was 6.2 (i.e., an average of 1.4 lambs per parity). Multiple-birth lambing is a frequent event in dairy ewes that positively affects its final profit. Ewes that give birth to multiple lambs usually produce more milk than do single-lambing ewes (El-Saied et al., 1999), mainly because of the hormonal effect of the placenta on the development of the udder during the gestation period and increased udder stimulation caused by the number of lambs reared.

Total revenues from milk and lambs during the lifetime of Churra ewes averaged 700 Euro. Averages for revenues per day for lifetime, productive life, and useful life were $0.30,0.60$ and 1.10 Euro, respectively. Total revenues from both milk and lambs increased by 11.5 and $11.9 \%$, respectively, from first to first and second parities and then from first and second to first, second, and third parity records. The corresponding increase in revenues from milk yield was only 2.4 and $11.3 \%$, respectively. Consequently, the lamb yield contributed more than milk yield to the final revenue for second parity. 
Table 5. Heritabilities $( \pm \mathrm{SE}$; bold and on the diagonal), genetic correlations ( $\pm \mathrm{SE}$; above the diagonal), and phenotypic correlations $( \pm \mathrm{SE}$; below the diagonal) among total lifetime performance traits. ${ }^{1}$

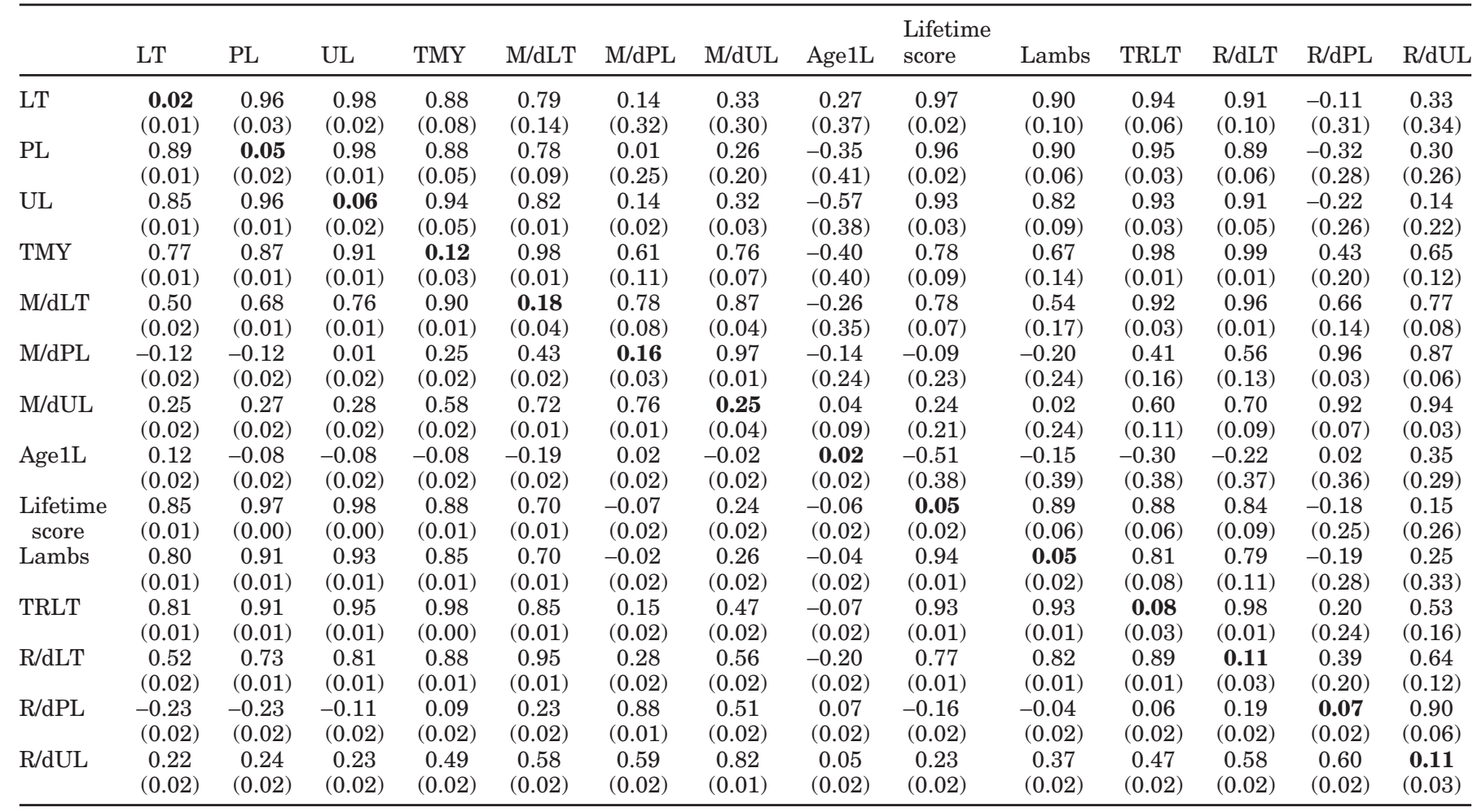

${ }^{1} \mathrm{LT}=$ Lifetime, $\mathrm{PL}=$ productive life, $\mathrm{UL}=$ useful life, $\mathrm{TMY}=$ total milk yield, $\mathrm{M} / \mathrm{dLT}=$ milk per day of lifetime, $\mathrm{M} / \mathrm{dPL}=\mathrm{milk}$ per day of productive life, $\mathrm{M} / \mathrm{dUL}=$ milk per day of useful life, Age1L = age at first lambing, lifetime score = number of given parities during LT, lambs = lambs sold at weaning during LT, TRLT = total revenue from milk and lambs during lifetime, R/dLT= revenue from milk and lambs per day of lifetime, $\mathrm{R} / \mathrm{dPL}=$ revenue from milk and lambs per day of productive life, and $\mathrm{R} / \mathrm{dUL}=$ revenue from milk and lambs per day of useful life.

On average, lambs contributed $42.5 \%$ of total revenues during the lifetime of the ewes compared with $57.5 \%$ for milk. These results show that lamb production is economically important for Churra breeders. Therefore, attention should be given to both milk and lamb yields in future profitability studies for Churra dairy sheep.

Table 4 presents analysis of variance of total lifetime performance traits. Both flock and year of birth within flock significantly affected all variables. Milk per day of useful life was included in the model as a covariable to adjust life span traits (lifetime, productive life, useful life, and lifetime score) for milk production level. Milk production level contributed significantly to variations in all life span traits.

Table 5 presents heritabilities and genetic and phenotypic correlations among total lifetime performance traits. Heritabilities were clearly low for life span traits (lifetime, productive life, useful life, and lifetime score) ranging from 0.02 to 0.06 . Conington et al. (2001) also reported low heritability (0.08) for longevity of Hill ewes in the UK. For dairy cows, Jairath et al. (1994) found that heritability estimates for productive life, useful life, and lifetime score were $0.08,0.09$, and 0.07 , respectively. In this study, heritabilities for age at first lambing, lifetime revenues from milk and lambs, revenue per day of productive life, and number of lambs sold at weaning were all low, ranging between 0.02 and 0.08 . These low heritability estimates suggest that direct selection to improve such traits would not be highly efficient. Therefore, genetic improvements for such traits should be made indirectly through correlated response when selection is applied to other correlated traits. Some passive selection for these traits takes place because individuals that live longer usually have more progeny.

Total milk yield during lifetime of the ewe had a moderate heritability ( 0.12$)$, but the per day milk traits for lifetime (0.18), productive life (0.16), and useful life $(0.25)$ had higher heritability estimates. Similarly, heritabilities for per day revenues for lifetime (0.11) and useful life (0.11) were somewhat higher than the estimate for combined lifetime revenues of milk and lambs (0.08). Jairath et al. (1994) explained that higher heritability estimates for per day traits are due to the standardization effect on per day traits by days of lifetime. 
Table 6. Heritabilities $( \pm \mathrm{SE})$ of selected partial lifetime performance traits and their phenotypic and genetic correlations $( \pm \mathrm{SE})$ with total lifetime performance traits. ${ }^{1}$

\begin{tabular}{lllll}
\hline $\begin{array}{l}\text { Total } \\
\text { lifetime } \\
\text { trait }\end{array}$ & $\begin{array}{l}\text { Partial } \\
\text { lifetime } \\
\text { trait }\end{array}$ & $\begin{array}{l}\mathrm{h}^{2}( \pm \mathrm{SE}) \\
\text { of partial } \\
\text { lifetime trait }\end{array}$ & Phenotypic & Genetic $( \pm$ SE) \\
\hline TMY & MY1 & $0.20(0.04)$ & 0.37 & $0.48(0.13)$ \\
& MY2 & $0.30(0.05)$ & 0.51 & $0.73(0.10)$ \\
MdLT & MY3 & $0.38(0.07)$ & 0.59 & $0.75(0.09)$ \\
& MdLT1 & $0.21(0.04)$ & 0.53 & $0.76(0.07)$ \\
& MdLT2 & $0.29(0.05)$ & 0.68 & $0.89(0.04)$ \\
MdPL & MdLT3 & $0.31(0.07)$ & 0.78 & $0.91(0.04)$ \\
& MdPL2 & $0.29(0.05)$ & 0.80 & $0.99(0.01)$ \\
MdUL & MdPL3 & $0.26(0.06)$ & 0.88 & $0.99(0.01)$ \\
& MdUL1 & $0.17(0.03)$ & 0.69 & $0.96(0.02)$ \\
& MdUL2 & $0.26(0.05)$ & 0.85 & $0.99(0.05)$ \\
TRLT & MdUL3 & $0.32(0.07)$ & 0.91 & $0.99(0.01)$ \\
& R1 & $0.14(0.03)$ & 0.26 & $0.18(0.20)$ \\
& R2 & $0.21(0.05)$ & 0.40 & $0.50(0.19)$ \\
& R3 & $0.25(0.05)$ & 0.47 & $0.69(0.13)$ \\
\hline
\end{tabular}

${ }^{1} \mathrm{TMY}=$ Total milk yield, M/dLT = milk per day of lifetime, $\mathrm{M} / \mathrm{dPL}=$ milk per day of productive life, $\mathrm{M} /$ $\mathrm{dUL}=$ milk per day of useful life, TRLT $=$ total revenue from milk and lambs during lifetime, MY1 = milk yield of first parity, MY2 = commulative milk yield of first 2 parities, MY3 = commulative milk yield of first 3 parities, M/dLT1 = milk per day of lifetime at end of first parity, M/dLT2 $=$ milk per day of lifetime at end of second parity, M/dLT3 = milk per day of lifetime at end of third parity, M/dPL2 = milk per day of productive life at end of second parity, M/dPL3 = milk per day of productive life at end of third parity, M/ dUL1 = milk per day of useful life at end of first parity, M/dUL2 = milk per day of useful life at end of second parity, M/dUL3 = milk per day of useful life at end of third parity, R1 = revenue from milk and lambs at end of first parity, $\mathrm{R} 2$ = revenue from milk and lambs at end of second parity, and R3 = revenue from milk and lambs at end of third parity.

Genetic and phenotypic correlations among total lifetime performance traits are given in Table 5. Both types of correlations were high among lifetime, productive life, useful life, total milk yield, lifetime score, number of lambs sold at weaning, total revenues from milk and lambs during lifetime, and revenues per day of lifetime. Genetic and phenotypic correlations among these traits averaged 0.90 and 0.87 , respectively. Similar results were found for Holstein cows by Jairath et al. (1994), who mentioned that high correlations among lifetime traits are attributed to the fact that many of the same factors are involved in controlling these traits. Correlations among the rest of the traits were low to moderate.

Total lifetime traits with the highest heritability in this study (total milk yield, milk per day of lifetime, milk per day of productive life, and milk per day of useful life) along with total revenues from milk and lambs during lifetime were chosen to estimate their performance early in life during the first 3 parities. Heritabilities of partial lifetime performance traits and their genetic and phenotypic correlations with total lifetime performance are given in Table 6. Except for milk per day of productive life, heritabilities for partial lifetime performance traits increased notably when more information (i.e., more parities) was included. In addition, both genetic and phenotypic correlations between total and partial lifetime traits increased gradually when more information was included in partial lifetime traits. These results coincide with those reported for Holstein cows by Jairath et al. (1994), who stated that high genetic correlations can arise from pleiotropy [same gene(s) involved in controlling same characteristics] and also because early life yield is a part of lifetime yield (i.e., a part-whole relationship). Therefore, a favorable correlated response is expected in total milk yield, milk per day of lifetime, milk per day of productive life, milk per day of useful life, and total revenues from milk and lambs during lifetime when early selection is carried out for their corresponding partial lifetime traits. For the last $5 \mathrm{yr}$, interest has been shown in genetic evaluation for udder and type traits for Churra ewes. As in the case of dairy cows, these traits may also be used in the future as possible indirect selection traits for longevity in dairy ewes. Currently, available data are not sufficient for such a study.

The highest heritability estimate for a lifetime trait in this work was that for milk per day of useful life $0.25( \pm 0.04)$. This trait is of a practical use, as it can be easily calculated at any time through the lifetime of the ewe. Heritabilities for partial milk per day of useful life for 2 parity (0.26) and $\geq 3$ parity (0.32) were greater than heritability for milk per day of useful life (0.11). Phenotypic correlations of these 2 traits with milk per day of useful life were obviously high ( 0.85 and 0.91 , respectively), and the corresponding genetic correlations were very close to one. Both traits seem suitable 
as early indirect selection traits to improve milk per day of useful life.

\section{CONCLUSIONS}

Direct selection is not recommended to improve total life span performance traits, as their heritabilities were clearly low. Based on the reasonable heritability estimates for partial milk per day of life span traits for 2or 3-parity records, especially for milk per day of useful life, and their high genetic correlations with total milk per day of life span traits, early, indirect selection to improve total lifetime merit is not excluded.

\section{REFERENCES}

Allaire, F. R., and J. P. Gibson. 1992. Genetic value of herd life adjusted for milk production. J. Dairy Sci. 75:1349-1356.

Baro, J. A., J. A. Carriedo, and F. San Primitivo. 1994. Genetic parameters of test day measures for somatic cell count, milk yield, and protein percentage of milking ewes. J. Dairy Sci. 77:2658-2662.

Boettcher, P. J., L. K. Jairath, and J. C. M. Dekkers. 1999. Pages 23-30 in Genetic Evaluation of Herd Life in Canada: Current Status and Future Outlook. Interbull Bull. No. 21. Jouy-en-Josas, France.

Boettcher, P. J., L. K. Jairath, K. R. Koots, and J. C. M. Dekkers. 1997. Effect of interactions between type and milk production on survival traits of Canadian Holsteins. J. Dairy Sci. 80:2984-2995.

Carriedo, J. A., J. A. Baro, L. F. de la Fuente, and F. San Primitivo. 1995. Genetic parameters for milk yield in dairy sheep. J. Anim. Breed. Genet. 112:59-63.

Conington, J., S. C. Bishop, B. Grundy, A. Waterhouse, and G. Simm. 2001. Multi-trait selection indexes for sustainable improvement of UK Hill sheep. In Proc. Br. Soc. Anim. Sci. Annu. Mtg., York, UK. Br. Soc. Anim. Sci., Edinburgh, UK.

Dekkers, J. C. M. 1993. Theoretical basis for genetic parameters of herd life and effects on response to selection. J. Dairy Sci. 76:1433-1443.

Dekkers, J. C. M., L. K. Jairath, and B. H. Laurance. 1994. Relationships between sire genetic evaluation for conformation and functional herd life of daughters. J. Dairy Sci. 77:844-854.

El-Saied, U. M., J. A. Carriedo, L. F. de la Fuente, and F. San Primitivo. 1999. Genetic parameters of lactation cell counts and milk and protein yields in dairy ewes. J. Dairy Sci. 82:639-644.

El-Saied, U. M., J. A. Carriedo, and F. San Primitivo. 1998. Heritability of test day somatic cell counts and its relationship with milk yield and protein percentage in dairy ewes. J. Dairy Sci. 81:2956-2961.

Fuertes, J. A., C. Gonzalo, J. A. Carriedo, and F. San Primitivo. 1998. Parameters of test day milk yield and milk components for dairy ewes. J. Dairy Sci. 81:1300-1307.

Gonzalo, C., J. A. Carriedo, M. A. Blanco, E. Beneitez, M. T. Juarez, L. F. de la Fuente, and F. San Primitivo. 2005. Factors of variation influencing bulk tank somatic cell count in dairy sheep. J. Dairy Sci. 88:969-974.

Groeneveld, E., and L. A. García Cortés. 1998. VCE 4.0, a (co)variance component package for frequentists and Bayesians. Proc. 6th. World Congr. Genet. Appl. Livest. Prod., Armidale, Australia. XXVII:455-456.

Jairath, L. K., and J. M. C. Dekkers. 1996. Genetic evaluation of functional herd life of Canadian Holsteins. Page 172 in Proc. Open Session of INTERBULL Annu. Mtg. Bull. No. 14. Int. Comm. Anim. Recording, Uppsala, Sweden.

Jairath, L. K., J. F. Hayes, and R. I. Cue. 1994. Multitrait restricted maximum likelihood estimates of genetic and phenotypic parameters of lifetime performance traits for Canadian Holsteins. J. Dairy Sci. 77:303-312.

Lormore, M. J., and D. T. Galligan. 2001. Economics of a typical lactation. J. Dairy Sci. 84 (E. Suppl.):E212-E215.

Mulder, H., and G. Jansen. 1999. Derivation of Economic Values Using Lifetime Profitability of Canadian Holstein Cows. Interbull Bull. 21:1-10.

Othmane, M. H., L. F. de la Fuente, J. A. Carriedo, and F. San Primitivo. 2002. Heritability and genetic correlations of test day milk yield and composition, individual laboratory cheese yield, and somatic cell count for dairy ewes. J. Dairy Sci. 85:2692-2698.

Pérez-Cabal, M. A., and R. Alenda. 2003. Lifetime profit as an individual trait and prediction of its breeding values in Spanish Holstein cows. J. Dairy Sci. 86:4115-4122.

Rogers, G. W., J. A. M. Van Arendonk, and B. T. McDaniel. 1988. Influence of involuntary culling on optimal culling rates and annualized net revenue. J. Dairy Sci. 71:3463-3469.

SAS User's Guide: Statistics, Release 6.12. 1998. SAS Inst., Inc., Cary, NC.

Van Arendonk, J. A. M. 1991. Use of profit equations to determine relative economic value of dairy cattle herd life. J. Dairy Sci. 74:1101-1107.

Visscher, P., R. Thompson, H. Yazdi, W. G. Hill, and S. Brotherstone. 2001. Genetic analysis of longevity data in the UK: Present practice and considerations for the future. www.boku.ac.at/nuwi/gift/ peter.pdf. Accessed Feb. 15, 2005.

Vollema, A. R., and A. F. Groen. 1995. Genetic parameters of longevity traits of an upgrading population of dairy cattle. J. Dairy Sci. 79:2261-2267.

Weigel, D. J., B. G. Cassell, I. Hoeschele, and R. E. Pearson. 1995. Multiple-trait prediction of transmitting abilities for herd life and estimation of economic weights using relative net income adjusted for opportunity cost. J. Dairy Sci. 78:639-647. 